\title{
Article
}

\section{Larissa Sansour and the Palestinian Ruins of the Future}

\author{
Duggan, Robert
}

Available at http://clok.uclan.ac.uk/33256/

Duggan, Robert ORCID: 0000-0002-4013-9002 (2020) Larissa Sansour and the Palestinian Ruins of the Future. Journal for Cultural Research, 24 (1). pp. 6983. ISSN 1479-7585

It is advisable to refer to the publisher's version if you intend to cite from the work. http://dx.doi.org/10.1080/00472336.2020.1767849

For more information about UCLan's research in this area go to http://www.uclan.ac.uk/researchgroups/ and search for < name of research Group>.

For information about Research generally at UCLan please go to http://www.uclan.ac.uk/research/

All outputs in CLoK are protected by Intellectual Property Rights law, including Copyright law. Copyright, IPR and Moral Rights for the works on this site are retained by the individual authors and/or other copyright owners. Terms and conditions for use of this material are defined in the policies page.

\section{CLoK}

Central Lancashire online Knowledge www.clok.uclan.ac.uk

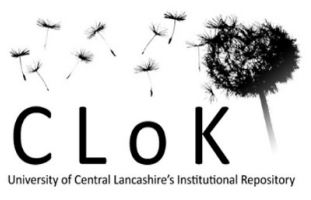




\title{
Larissa Sansour and the Palestinian Ruins of the Future
}

\section{Robert Duggan}

\section{University of Central Lancashire}

\begin{abstract}
This article considers how the work of artist Larissa Sansour in A Space Exodus (2009), Nation Estate (2012) and In the Future They Ate from the Finest Porcelain (2016) represents a compelling series of oblique engagements with Palestine's historical predicament through both comic and poignant deployment of science fiction's enduring fascination with historicity and the ruins of the future. In tracing how her films situate their narratives in relation to famous examples of science fiction as well as the politics of archaeology and architecture, I am seeking to place Sansour's complex play with temporality at the heart of both a key tradition in science fiction and the ongoing stasis that continues to beset Palestinians today.
\end{abstract}

\section{Keywords}

Larissa Sansour, Palestine, science fiction, ruins of the future, archaeology, 


\section{Larissa Sansour and the Palestinian Ruins of the Future}

Larissa Sansour has emerged as one of the most thought-provoking and original artists currently exploring Palestine and Palestinian identity and her works' adaptions of ideas and tropes from science fiction has won her a wide range of admirers and prizes. Her series of films and related installations and exhibits since 2009's A Space Exodus have been displayed in galleries, museums and shown at film festivals across Europe and the Middle East and she represented Denmark at the 2019 Venice Biennale. The subject of apparent censorship attempts ${ }^{1}$, Sansour has pursued her own idiosyncratic yet recognizable visions of Palestine's past and future in Nation Estate (2012) and In the Future They Ate from the Finest Porcelain (2016). This article considers how her work represents a complex and compelling series of oblique engagements with Palestine's present predicament through both comic and poignant deployment of science fiction's enduring fascination with historicity and the ruins of the future. In tracing how her films situate their narratives in relation to famous examples of science fiction including Kubrick's 2001: A Space Odyssey and George Orwell's Nineteen Eighty-Four, I am to seeking to place Sansour's play with temporality at the heart of both a key tradition in science fiction and the ongoing stasis that continues to beset Palestinians today.

In the course of his magisterial The Question of Palestine (1979) which makes an eloquent case for Palestinian self-determination, Edward Said is sensitive to the peculiar temporal dimensions of the place and its people. In terms of Palestine's status as a country he claims:

The fact of the matter is that today Palestine does not exist, except as a memory or, more importantly, as an idea, a political and human experience, and an act of sustained popular will. (p. 5)

For Said, writing in 1979, Palestine has not achieved statehood and cannot be said to exist in a tangible material way. Without a designated government and without set borders and its own legal and constitutional order, Palestine can only persist in ways heavily mediated by time. In the quote above, Said points to Palestine's existence as a memory, one that is personal for those who remember the pre-1948 era, and collective for their descendants. As 'an act of sustained popular will' Palestine is also a set of ongoing social and cultural practices as well as a current political cause that draws attention from all over the world. '[M]ore importantly' however, Palestine exists as an idea, and here Said hints at the future possibilities this idea may engender. Palestine, for Palestinians, is both what has been lost, and potentially what will have been created, or perhaps restored, these moments in time bridged by a contemporary present defined by absence and stasis. It is this paper's contention that the most productive way of thinking about Larissa Sansour's art is to apprehend it working in all of these directions at once. Her works strive against the disappearance of the past on the one hand and for the imagining of a future on the other, and invites the viewer to understand the contemporary Palestinian moment not as an already-known reality but as a specific moment in an ongoing temporal chain, a definite absence that continues and carries within it the future possibility of presence.

The persistence of the Palestinians as a nation is the result of what Said terms 'an act of sustained popular will', and he asserts in his introduction to Joe Sacco's 
graphic novel Palestine (2001) that a fundamental aspect of Sacco's achievement is the visual representation of Palestinians as living realities, making visible their existence, alternatively mundane and dramatic. As Cristina Delgado-García (2015) points out in relation to the same book:

its production of space is crucial to the configuration of a Palestinian identity, which is defined in spatial terms for its displacement, dispossession, entrapment, and will to re-signify a land that is materially and symbolically unstable. (Delgado-García)

It is out of this contemporary moment of stasis for Palestinians that Sansour's projects emerge and it is this very stasis that her works critically interrogate and playfully deform, bending the rules around what has happened and what might occur in the future. Her temporal experiments thus partake in what Fredric Jameson in Archaeologies of the Future (2005) terms science fiction's 'structurally unique "method" for apprehending the present as history... irrespective of the "pessimism" or "optimism" of the imaginary future world which is the pretext for that defamiliarization' (p. 288). Science fiction thus furnishes us with literary and cinematic examples through which we become aware of the historicity of the present, regardless of whether we find the imagined future staged before us appealing or not. Larissa Sansour's art, as this article will show, embraces the potential of this structurally unique method in apprehending the Palestinian present as history, and her films show a growing engagement with the complexities of science fiction's temporalities and a deepening relationship with that early but seminal and enduring achievement of sci-fi, the ruins of the future.

Sansour first came to widespread attention with her 2009 film A Space Exodus, a short (6min-long) film that depicts a fantasy moon landing, where the artist in a specially-badged white spacesuit and boots with curled toes is shown planting a Palestinian flag on the moon, and later slowly rotating in space to the sounds of an Arab-inflected techno version of Johann Strauss's Blue Danube in a nod to Stanley Kubrick's 2001: A Space Odyssey. While humorously drawing on real NASA experiences (at one point Sansour says into her radio "Jerusalem we have a problem") and riffing on iconic images and music from the Kubrick film, A Space Exodus ends in less light-hearted fashion, as the astronaut-creator seems to fall away from the viewer until she vanishes into the empty depths of space. The film finishes with the artist in her space-suit spinning weightlessly in the void, audibly breathing, then rapidly receding from view, asking for Jerusalem but getting static in response, evoking the death of Dave Bowman's crewmate in 2001 who is killed by the supercomputer HAL and whose body floats into space until retrieved by Bowman. $A$ Space Exodus's play with the iconography of the moon landing and space films is done in an entertaining way, comically inserting recognizable moments (both factual and fictional) of triumph and achievement in space into a specifically Palestinian narrative. Despite this, the ominous ending undercuts the earlier images of the triumph of landing on the moon, and makes for a far more ambivalent conclusion, albeit one lacking closure, than the wish-fulfilment aspect of the scenario might lead viewers to expect. Such ambivalence is a recurrent feature of her work, as I will go on to show below. 
As a Bethlehem-born, London-based artist, Sansour is often asked in interview to describe her relationship to Palestine, and in particular about her perhaps surprising choice of science fiction as an artistic mode. In her responses she has been keen to draw attention to the power of science fiction narrative and myth-making rather than the trappings and props of space opera:

You know, spaceships and bombs are not things that are important to my film, obviously; but they elevate a Palestinian narrative to one on par with those of the rest of the world. Glossy sci-fi is preferable to us always being the subjects of documentaries, which is something I think is hurting us, more than anything. (Abdeljawad 2016)

Here more emphasis is placed on the authorship of narrative rather than its mode, and Sansour directly opposes glossy sci-fi by Palestinians to political documentaries about Palestinians, with sf posited as a narrative that does something different to conventional news stories about protests and attacks. The prevalent experience of being subordinate to someone else's master narrative is superseded on an imaginative level in the film by the physical and metaphoric elevation of a Palestinian, and Palestinian symbols including the flag, to iconic status where they become generalised signs of human aspiration, not parochial symbols of narrow nationalism.

In tension with this elevation however sits A Space Exodus's menacing ending, an ominous note also suggested by the film's multivalent and overdetermined title. The use of the term Exodus has a clear Biblical dimension, alluding to the book in the Bible in which the Israelites escape slavery in Egypt and make their way to the promised land. More contemporary uses of the term, for example in Leon Uris's blockbuster novel Exodus (1958) and the successful film version directed by Otto Preminger (1960) position the escape of Jews from a Europe riven by war and genocide and their journey to what will become Israel as a modern echo of this Biblical narrative of escape from bondage. Sansour has stated that the reception of Uris's book and the film based on it has damaged the perception of Palestine and contributed to the narrative of 'a land without a people for a people without a land' (Bouarrouj 2015). Her use of the term as a title introduces a more plaintive note into this dazzling space journey - is it an escape? If so, from what? The Palestinian astronaut walks on the moon in 'conquest' but ends up alone, floating away into empty space, disconnected from her homeland. The term Exodus also connotes the experience of displacement for so many Palestinians since the Nakba, the Catastrophe of 1948 in which hundreds of thousands of Palestinians fled their homes, never to return, and this sense of lonely departure forms a powerful subtext for the film, in which the pain of enforced exile is felt alongside the triumph of technology. Sansour perceives a 'retro' aspect in much mainstream sci-fi where the future technologies seem both novel and clichéd, however she also finds that an artist creating works about Palestine will be sensitive to how 'the odd mix of nostalgia and accomplishment that the sci-fi genre often embodies lends itself well to the topic' (Bouarrouj).

The characteristic temporality employed in science fiction offers Sansour particular advantages as an artist exploring Palestinian identity, helping to produce work that provides viewers with a quite different perspective to that offered by conventional reportage, as she has made clear in interview: 
Sci-fi has a cyclical nature that works very well with the Palestinian condition, because we always project a state; but at the same time, we always talk about the Nakba so there is always this dialogue between nostalgia and ambitions for the future. The present is kind of lost in documentaries; it lives in this state of limbo, it isn't real. That's why I think sci-fi works really well. (Abdeljawad)

This sense of a Palestinian present as a condition of suspension, of uncertain ontological status, has clear echoes of Said's earlier claim that Palestine does not exist and refocuses our attention on potential futures. Given the losses of the past, and the void of the present, what does the future hold for Palestine? Questions of teleology have underlined so much science fiction involving time travel from HG Wells onward, and imagining the future seems a fundamental, if not the fundamental, feature of sci-fi viewed as a genre. Science fiction from the Arab world has been receiving more attention from the West, both in terms of translating texts from Arabic into English and in terms of critical attention from scholars working elsewhere in the world, including Ian Campbell whose Arabic Science Fiction was published in 2018. While it is possible to align Sansour's work within a broader tradition of Arab science fiction, it is important to register how her films are infused with very context-specific concerns around teleology that come from the history of Israel/Palestine, and that are born of the human experience of altered and shattered chronologies. Equally germane perhaps to Sansour's particular use of science fiction in her films are earlier artistic examples of Afrofuturism, defined by Kodwo Eshun (2003) as:

a program for recovering the histories of counter-futures created in a century hostile to Afrodiasporic projection and as a space within which the critical work of manufacturing tools capable of intervention within the current political dispensation may be undertaken. (p.301)

The twin historical and current political focus of Afrofuturism as it is defined by Eshun find its echo in Sansour's use of science fiction's temporal reframing.

The lack of progress in resolving the question of Palestine has in some ways become its defining feature in the popular imagination of those unconnected to the region, with the intractability of the conflict frequently alluded to even by those assigned to find solutions. Shimon Peres who served as Foreign Minster and Prime Minster of Israel, sometimes described the conflict as having a light at the end of the tunnel, but that the tunnel was missing ${ }^{2}$. The metaphor supposed that the goal of a two-state solution, with Israel and Palestine living peacefully side-by-side was theoretically possible but there did not seem to be a political mechanism through which it might be achieved: the gap between the conflict of the present and a peaceful future remained. For others however, the absence of the tunnel meant that the light of a peaceful future was unlikely ever to materialize. Moshe Dayan, an Israeli general and minister said in 1968 'The question is not "What is the solution?" but "How do we live without a solution?", (Siegman, 2018, p. 17). From a twenty-firstcentury Palestinian perspective, the nightmare of history can be felt as an ever-present disorientation, not an event consigned to the past. The celebrated poet Mahmoud Darwish, in a speech given in 2001 held that 'the present is a living reminder of the catastrophe, the Nakba, the tragic events of which are still unfolding' (Darwish). Such temporal formulations render the current Palestinian present as one characterised by 
absence of agency, stasis and erasure, a mode of being without sight of the future, doomed to remain in limbo. This lived experience of social and political inertia has in recent Palestinian art become an all-encompassing condition, memorably presented in director Elia Suleiman's absurdist film Divine Intervention (2002) which stages endless, Beckettian waiting for something that never arrives, as the characters repeat their futile tasks in endless cycles. In the run-up to the 2019 Israeli general election, Palestinians were noted for their apathy as to the result, with the front running candidates offering no more difference from a Palestinian perspective than two alternative brands of cola. ${ }^{3}$ Sci-fi for Sansour then is a way of looking outside the current stasis, to both the past and the future, rather than staying in 'the tunnel' repeating the same points and the same arguments over and over again. Rather than evoking the Sisyphean experience of a changeless Palestinian present, as Suleiman's film does, Sansour's art takes the idea of an imagined Palestine, and projects it into the future, with surprising and contradictory results. Her subsequent major work Nation Estate accelerates and deepens this developing sense of Palestinian futures, full of glossy high-tech promise but shadowed by a mournful mood of loss.

Nation Estate is a film installation that begins with a passenger riding an underground train that the automated voice identifies as the Amman Express. The camera follows the passenger, played by Sansour, as she exits the train wheeling a small suitcase and uses escalators to ascend to a vast lobby, where she undergoes an eye-scan to gain entry and walks past a large Palestinian flag on the wall. Through the windows of the lobby we briefly see a large grey wall with watchtowers. Next to the lobby's lifts is a list, under the heading of 'Nation Estate', of significant Palestinian sites including Bethlehem and Jerusalem, each of which has been assigned a floor number. As she waits for the lift, the passenger looks at a brightly-coloured poster depicting a high-rise apartment block called Nation Estate, captioned 'Living the High Life'. The passenger, who doesn't speak for the entire film, enters the lift and as the lift moves up the floors, advertisements for businesses and services are displayed, including a reminder that passengers need to have their Nation Estate passports validated in order to travel. Two other passengers get off at the Jerusalem floor, where the Dome of the Rock is visible, and the woman leaves the lift when the doors open at 'Bethlehem', walking into a huge bright chamber that seems to be a replica of the town, in which ancient stone walls are undercut by modern white tunnels. After walking down a tunnel to the sound of church bells, the woman with the suitcase uses an electronic keycard marked with the Palestinian flag, and enters an apartment where she waters an olive tree and uses some high-tech containers to prepare traditional Palestinian food in keffiyeh-patterned bowls. She is shown to be pregnant and when she makes the apartment window transparent, a distant view of Jerusalem is revealed, as golden light falls on the Temple Mount. The films ends with a close-up of Sansour's face and then the camera pulls back further and further to show that the character is in one apartment of countless thousands in a vast glittering high-rise building that is surrounded by a prison wall and watchtowers.

As with A Space Exodus, the viewer is provided with some of the visual pleasures of a spotless and impressively shiny high-tech world, and Nation Estate can be read as exchanging the perspective of a distant astronaut for one of a mother-to-be that is (literally) more down-to-earth. Of course what strikes the viewer in this comparison is the remarkable similarity in their positions: the Nation Estate dweller may be geographically much closer to Jerusalem, but she is ultimately an exile too, a 
prisoner in a simulacrum Palestine who can 'enjoy' glossy replicas of well-known places but who is not granted free access to the real places. Like the astronaut on the moon, she can look longingly at Jerusalem but not reach it, and the viewer wonders what life will be like for her and her child, as she rapidly recedes from the viewer's gaze like the ending of the earlier film. In similar fashion to the A Space Exodus's fun with technology, the dazzling promise of a future where technological advances will have solved so many challenges for human beings is shown at the end of Nation Estate to have left Palestinians in a very similar position to where they are now, enmeshed in systems of control and surveillance, their 'footprint' gradually shrinking until Sansour presents us with the entire Palestinian nation squeezed into one gigantic building in the West Bank, accessed via a sealed tunnel to Jordan. The 'retro' aspect of sci-fi noted by Sansour earlier has here become more distinct, the landmarks and signs of tradition mixed up with a scientific sublime of smooth-running machinery but where in Sansour's words the state of Palestine is 'planted in the past, like a relic, or firmly looking towards the future, but never as a viable condition in the present' (Bouarrouj). Systems of control, through travel documents, iris scans and fingerprinting multiply as part of an all-powerful security apparatus in this polished version of the future. To return to Perres's metaphor, there is a tunnel in Nation Estate, but the gleaming futuristic 'solution' at the end of it is revealed to be as much nightmare as dream.

As Bill Ashcroft notes in his discussion of Nation Estate in Utopianism in Postcolonial Literature (2017), the 'Living the High Life' poster seen in the film adopts the highly-coloured style of Franz Krausz's 1936 'Visit Palestine' advertising poster for the Tourist Development Association of Palestine, made famous when it was reproduced in the 1990s and found immense popularity with the public. The original poster shows a stylized view of the Dome of the Rock/Temple Mount in Jerusalem and was repurposed by Palestinian artist Amer Shomali in 2009 when he placed an image of the Separation Wall in the centre of his poster, entirely 'blocking' the view of the city seen in Krausz's original (see Davis and Walsh 2016). Sansour's poster reproduces the frame of an olive tree but depicts a large tower on a platform in place of the holy sites of Jerusalem. So within the film, echoes of the past (the poster, the food, the olive tree) are recast in a gleaming but sterile simulacrum of Palestine, where all Palestinians have left their homes and reside in a high-rise tower block. The real places referred to (Jerusalem, Bethlehem, Nazareth) appear to be off-limits to the inhabitants of Nation Estate, as they are cut off behind a large barrier. The 'stacking' of the different areas of Palestine into a single block recalls the 'politics of verticality' originally analysed by Eyal Weizman in his influential Hollow Land: Israel's Architecture of Occupation (2007) in which the space of Israel/Palestine has been split into 6 dimensions, 3 Israeli and 3 Palestinian, and the West Bank is used as a kind of laboratory for experiments and new techniques and structures in control, surveillance and warfare as tunnels and towers transform the land. Revisiting the book ten years after its publication, Weizman sees the expansion and growth of such verticality:

I have called this layered political structure 'the politics of verticality'. Throughout the last decade, this evolving and elastic territorial architecture has hardened into a permanent mechanism of separation and control. Verticality has become a form of apartheid. The word should in fact be synonymous with it. (Weizman, 2017) 
Nation Estate's high-rise can been seen as the fantastic but perhaps disturbingly familiar apotheosis of such policies, the hardening of verticality into 'a permanent mechanism of separation and control'.

The leap into a future in Nation Estate became a central focus of Sansour's next major project In the Future they Ate from the Finest Porcelain (2016) directed by Sansour and her husband Søren Lind. The film follows a conversation in Palestinian Arabic between two women, one of whom styles herself as a 'narrative terrorist' and who is being questioned by the unnamed other, the end credits identifying the speakers as 'resistance leader' and 'psychiatrist'. The dialogue with English subtitles plays over of a series of images and segments that seem to be the dreams of the resistance leader (voiced by Sansour but played by Pooneh Hajimohammadi), describing her relationship with her sister who died as a child, and explaining her project to interfere in the history of her world. She tells the psychiatrist that she is planning to manipulate the carbon-date of porcelain bowls with a specific pattern (the images show bowls made with the traditional keffiyeh pattern used in Palestinian scarves). She will then plant them in the ground, in order to change how future archaeologists will understand the past, so that the people of the future will have a different idea of her community, and will claim kinship with them and with the place. The viewer sees the resistance leader's dreams being staged, as a storm of porcelain falls from the sky and she moves inside a tableau made of pictures from Palestine's past, from subtly-animated nineteenth-century photographs of Bedouin figures, to images of Mandate soldiers and missionaries. In one section, the resistance leader sits motionless at the centre of a table in an echo of Leonardo da Vinci's Last Supper, gazing at the camera and flanked by different people from the past of this place, including soldiers, ragged children, Christian clergy, people having dinner and a woman in traditional elaborate head-dress. In a number of scenes the resistance leader is initially motionless, so that her movement after several seconds comes almost as a surprise. In the final 'Last Supper' scene, she sits perfectly still as the camera slowly zooms in on her face and only at the end does she conspicuously blink, showing that she is not an image from the past in a static tableau but a living person.

The conversation between the two speakers debates the practicality and motives of the resistance leader's plans, and the conditions her community endure in this unnamed place that 'was always a barely functioning dystopia'. In the background, a singer performs 'Al Rosana', a Palestinian folk song about the eagerly awaited arrival of an Italian ship during a famine that once docked was found to have nothing useful on board ${ }^{4}$. Against a background of disappointment and disappearance, the resistance leader has decided to strike back, not directly at the rulers of the place, but at the historical narrative that underpins their power over her community. Weapons have been replaced by artefacts. We see space-craft flying over a desolate, orange-coloured landscape with only brief glimpses of glittering cities in the distance. Later in the film bombs are dropped far up in the sky, drifting down under parachutes to fall on the ground and break open, disgorging the keffiyeh bowls, which look very similar to the ones used to serve food in Nation Estate. Archaeology in Absentia, an exhibition that accompanied In the Future displays a series of stylized bombs, and shows how fifteen porcelain bowls like the ones we see on screen have actually been buried in the West Bank, with GPS locations provided, so that the project acts out and documents this experiment with the future. In the Future They Ate from the Finest 
Porcelain is arguably the most 'present'-focused of the films, precisely because of the efforts of the protagonist to try and preserve parts of the past, to hold on to the memory of her sister, and simultaneously generate some sort of future for her people. The title's play with tense signals the temporal reframing the protagonist is trying to effect, to work in the present to alter the past of the future. The psychiatrist casts doubt on the resistance leader's plans to 'hack' the archeological record used to bolster an oppressive power, and dismisses her chances of success, and the viewer is left to meditate on the limits of our ability to imagine the future. It is also tempting to read the debate around the resistance leader's methods as a distant echo of Sansour's position as a Palestinian artist who creates science fiction, playing with time and disrupting conventional narrative temporalities through the introduction of unreal archaeology.

Archaeology in Israel and Palestine is a hugely politicized endeavour, as findings from the field are frequently interpreted in relation to existing historical and scriptural narratives about the land and its peoples, so it is perhaps not surprising that Sansour's In the Future spends time reflecting on the privileged status of archaeology within discourse around identity and belonging. Nadia Abu el-Haj in Facts on the ground: archaeological practice and territorial self-fashioning in Israeli society (2002) interrogates the cooption of archaeology into political narratives and of course the very title of her work is a deliberate echo of Israeli government policy of settlement growth in the West Bank to establish 'facts on the ground' that will permanently change the character of the place, superseding any arguments in law courts about questions of jurisdiction and sovereignty. In the Future develops the idea of archeological findings being taken as 'facts' and evolves it into a futuristic scenario in which a character deliberate seeks to 'hack' the archeological record for political purposes by introducing objects that have been artificially aged, producing 'facts' that will establish a future national narrative for a future people. When describing her group's activities, the resistance leader in Sansour's film shows herself going one step further in manufacturing facts in the ground, telling her interlocutor that 'We are depositing facts in the ground for future archaeologists to excavate'. The character's act of resistance takes place not on the streets but in creating a counternarrative of archeological 'fact' to oppose the hegemony of the 'masters'.

The history of archaeology in the 'Holy Land', as the designation suggests, has long been pre-occupied by Biblical narrative, with the buried city rather than the one that can be seen. As Eitan Bar-Yosef describes

[The Palestine Exploration Fund, founded 1865] justified the poor results of the excavations by explaining that it was all a matter of depth; it sought to unearth a Judeo-Christian reality beneath the Muslim present, while gratifying the Protestant suspicion of the Catholic holy places; and it echoed the fascination with other buried cities, typical of the Victorian preoccupation with roots, origins, and beginnings. Significantly, it proposed to do all this by deferring, yet again, the visible earthly city. (pp. 178-9)

The material reality of city life in Palestine was (not for the last time) endlessly deferred in favour of the promise of truth buried deeper under the ground, a tendency that arguably continued after the creation of the state of Israel (see Ch. 5 Abu el-Haj). The resistance leader in Sansour's film wants to tap into this thirst for origins, by 
infiltrating the interpretation of antiquities, subverting the master narrative and offering a tangible form of continuity for a population to come. She tells the psychiatrist that 'in its most perverted form, archaeology galvanizes public sentiment, confirms myths of the past and defends them against scrutiny. Now we are part of that game too'. Interestingly, the character affirms that this is not a matter of truth or historical fact claiming that 'scientific rigour is irrelevant' as academic discipline has already been degraded and channeled into the reinforcement of existing claims to territory and control. She dreams of lying on her deathbed 'making my civilization's Shroud of Turin', a 'fake' relic that will come to be venerated by the faithful. It will not matter that the artifact is a manufactured hoax, what will matter is its 'aura' of authenticity, for the people of the future who will find an image of themselves within it. Only through such future contemplation will its potential to contest the narrative of the unnamed 'masters' be realized.

The hunger for ruins and relics of the past has a long history, as Brian Dillon outlines in his book Ruin Lust (2014) which accompanied an exhibition of the same name at the Tate gallery in London. For Dillon 'the ruin lust of the eighteenth century begins in part as a way of thinking about - fearing and hoping for - the future' as it 'traffics with more than one timeframe' (p. 48) and the painting and literature of the period sees an escalation in carefully staged ruin contemplation. The most influential text in this regard is Constantin-Francois Volney's The Ruins: or a survey of the revolutions of empires, first published in French in 1791 and in English the following year. A philosophical exploration of the development of religions and a critique of empires, Volney's description of ancient ruins surrounded by desert quickly became a commonplace of Orientalist painting and literature. In The Ruins the European protagonist's meditations on time as he contemplates the ruins of Palmyra (ruins sadly further destroyed by the recent depredations of ISIS) became a touchstone for Romantic writers, helping to inspire works including Percy Bysshe Shelley's 'Ozymandias', as Cian Duffy explores in The Landscapes of the Sublime 1700-1830 (2013). In Mary Shelley's Frankenstein: or the Modern Prometheus (published the same year as 'Ozymandias') Volney's book is read to Safie 'the Arabian' as she is educated by Felix in the De Lacey household, with Victor's creature overhearing the lessons and being similarly moved by their insights:

The book from which Felix instructed Safie was Volney's 'Ruins of Empire'... I heard of the discovery of the American hemisphere, and wept with Safie over the hapless fate of its original inhabitants. (p. 119)

In addition to these reflections on the history of civilizations, Volney's work has become known as one of the first literary instances where the temporal reframing instigated by such encounters with decayed antiquities gives rise to the civilization of the artist's present being reimagined as the ruins of the future. Near the beginning of the narrative, the protagonist is moved by the desolation of Palmyra to imagine the same fate befalling his own country and asks:

Who knows but that hereafter some traveller like myself shall sit down on the banks of the Seine, the Thames, or the Zuyder Sea... solitary amid silent ruins, and weep a people inurned, and their greatness changed into an empty name? (Volney p. 12) 
The ruination of so grand a place as Palmyra induces thoughts of the fragility of all empires and cities, including those close to home. This special kind of ruin contemplation has been identified as a key feature of science fiction, as John Clute and David Langford (2019) argue:

The fully-developed topos - where our contemplation of the past is syntactically and imaginatively parlayed into a fully imagined future observer's own story-embedded contemplation of our present world - first seems to appear in Les Ruines, ou méditation sur les révolutions des empires by M Volney, published only two years after the future-creating paroxysm of the French Revolution... (Clute and Langford)

As they point out, this kind of imaginative scenario comes into being at the same time as the French Revolution, and they suggest that that the political revolution enabled a view of the present as a distant past moment of the future, only partially deciphered by a witness. The radical break with the past brought into being by the Jacobins, famously enshrined in the new revolutionary calendar which renamed the months of the year and the days of the week, finds its corresponding echo in the present imagined as the enigmatic and deeply foreign ruins of the future: ' $\mathrm{sf}$...in this context might be defined as that literature which narrativizes the gap between Ruins and Futurity'.

If indeed sf is that which artistically attends to the gap between ruins and futurity, then we can begin to regard In the Future as being very far from a quirky embodiment of purely 'local' concerns but instead as engaging with a fundamental aspect of science fiction in all the power of its focus on the nature of futurity and our relationship to it. The political events in Israel/Palestine might be seen from a Palestinian point of view as potential future-destroying paroxysms, rather than the future-creating ones of 1789 , in that they seem to mark the end of a hope for a Palestinian state. However, it is the temporal reframing that has been a core component of science fiction since its beginning that enables Sansour as an artist to create work which can open up new perspectives on the present, as she makes clear in interview:

Science fiction allows for a flexible reshuffling of time frames. A break in chronology is often necessary in science fiction as realities are forecast in the future or reenacted from the past. A constant in work that uses science fiction is an urgent need to make sense of either the past or the future. It has this inherent quality of interlinking time capsules in a posited formula that replaces what would otherwise be conventional dialogues refraining to the same issues. (Stolfi 2016)

The ongoing crisis of Palestine and the Palestinians where there is little sign of any progress or positive change may through the deployment of science fiction take new shapes that can re-engage our imaginations, narrativizing the gap between the catastrophe of the past and a different future, mediated through a stagnant present.

The idea of controlling the future through controlling the past brings to mind Winston Smith's job in Nineteen Eighty-Four altering records so that all existing documents will reflect current Party 'facts'. When discussing In the Future in 
interview Sansour has directly alluded to George Orwell's novel, and quoted the Party slogan 'who controls the past controls the future, who controls the present controls the past' (Stolfi) that O'Brien asks Winston to recite when he has been imprisoned. Sansour's resistance leader is attempting to break up the conventional narrative being constructed about the past by adding some new pieces of her own fabrication (in both senses of the word). The dialogue between the resistance leader and the unseen person listed as 'psychiatrist' in the film's credits takes place in an unclear context, and their conversation creates an element of doubt as to the psychiatrist's motives and even identity:

RL have we had this conversation before?

$\mathrm{P} \quad$ what do you think?

RL that depends

$\mathrm{P} \quad$ on what?

RL on you being who you say you are

While there are not clear signs that the conversation occurs under duress, the exchange above hints that it might be an interrogation rather than a conventional counseling or analysis session. In this it shares similarities with the torture episode in the Ministry of Love, where O'Brien 'had the air of a doctor, a teacher, even a priest' (p. 257) despite the fact he is torturing Smith with electric shocks. O'Brien with his gentle bedside manner tells Smith he wants to help and cure him but also points to the futility of Smith's attempts to adhere to a truth outside the Party's control and leave a diary that is addressed 'to the future, or to the past' (p. 30) for future generations to read:

'And above all we do not allow the dead to rise up against us. You must stop imagining that posterity will vindicate you, Winston. Posterity will never hear of you. You will be lifted clean out from the stream of history. We shall turn you into gas and pour you into the stratosphere. Nothing will remain of you, not a name in a register, not a memory in a living brain. You will be annihilated in the past as well as in the future. You will never have existed.' (pp. 266-7)

O'Brien's undertaking is terrifying in its temporal scope and nightmarish ambition and reminds the reader of the woman earlier in the novel who worked in the next cubicle to Smith's, erasing the names of those vaporized from all records. It is against such a disappearance that the resistance leader strives, although in an echo of Smith's doubts when starting his journal, the psychiatrist tells her 'You are devoting your life to communicating with the past and the future, but it's impossible'.

Dreams in Nineteen Eighty-Four play a prominent role in the novel's exploration of private memory and desire, and there is one dream that Smith has soon after he starts his diary that bears a striking resemblance to a scene near the end of In the Future. Winston is dreaming of his mother and his sister, both of whom died a long time ago, and who he feels in an obscure way have sacrificed themselves to save him:

At this moment his mother was sitting in some place deep down beneath him, with his young sister in her arms. He did not remember his sister at all, except 
as a tiny, feeble baby, always silent, with large, watchful eyes. Both of them were looking up at him. They were down in some subterranean place - the bottom of a well, for instance, or a very deep grave - but it was a place which, already far below him, was itself moving downwards. (p. 33)

Smith has spent his working life destroying records and counterfeiting the past, and worries about its disappearance, and his dreams about his mother and sister are entwined with this anxiety about the loss of the past so that 'the rewriting of political history in Oceania is assimilated to the personal dreams of a lost childhood' as Jameson puts it (p. 200). At the very end of the novel Smith has a happier childhood memory of laughing with his sister and mother as they played snakes and ladders, but in his 'cured' state he pushes it away as a false memory, not responding to a fragile and momentary but authentic link to his past.

In the Future connects the personal and the political in strikingly similar ways, so that the 'rewriting' of the archaeological record is 'assimilated to personal dreams' of a lost sister, as in Smith's case. Near the end of the film, the resistance leader stands with a shovel at the top of a deep cylindrical hole much like a well, the movement of her closed eyes suggesting REM dreams. At the bottom of the dark hole crouches her sister costumed in traditional dress looking back up at her and the viewer is struck by the immense gulf that divides the sisters as the resistance leader gazes down over the rim of the hole. The girl's head drops and she recedes down into the blackness, like Smith's sister. Around the edge of the well or grave lie scattered pottery bowls, presumably waiting their interment, creating a clear correspondence between the lost sister and the pottery. The scene is both burial and exhumation, both of the pottery and of the memory of the girl, the placement of things where they can be preserved for future excavation and identification. Buried in the past, the girl who was killed when she was nine years old by people who didn't know what she was, synecdochically stands for a whole people, as the resistance leader remarks 'after a certain point, death is no longer about the single life lost. It's not even personal. It's what we are as a whole that qualifies us as targets.' The buried child haunts the present and the porcelain bowls with the keffiyeh pattern are a link to this past, hidden inside bombs casings seen dropping from the sky but then buried beneath the ground awaiting discovery by a posterity with the capacity to claim them as its own. If, as Abu el-Haj suggests, 'Observable empirical facts - "Israelite" pottery, in this instance - formed the foundation of archaeological knowledge and became the terrain of historical argument' (p. 129), then for the resistance leader the keffiyeh pottery might fulfill a similar function in an imagined future. 'Our rulers' the resistance leader tells the psychiatrist 'built a nation on archaeology' and now she wishes to do the same. Neither the legitimacy of their cause nor the 'truth' of the past can help them, according to the leader, only the disruption of the smooth running of the rulers' fiction. This dominant fiction is one in which the rebels literally have no place, and do not and never have existed - deliberately unseen by the rulers, only visible when they rebel.

The potential obliteration of the past seen in Nineteen Eighty-Four, Jameson suggests, will give way in later science fiction to fears about the disappearance of the future: 
Perhaps indeed we need to develop an anxiety about losing the future which is analogous to Orwell's anxiety about the loss of the past and of memory and childhood... it would be a fear that locates the loss of the future and futuricity, of historicity itself, within the existential dimension of time and indeed within ourselves. (p. 233)

Jameson proceeds to discuss Marge Piercy's sf novel Women on the Edge of Time and Chris Marker's film La Jetée in the context of this fear of the loss of the future and we might be inclined to place In the Future among these texts. The film evokes the loss of the past understood both on a personal and a collective level, but crucially also ponders the possibility of a distant future that can only be blindly postulated and that exists under a general threat of foreclosure. What the 'resistance leader' is actively resisting is precisely this foreclosure, disagreeing with the psychiatrist who tells her these descendants will never exist. Like the ending of A Space Exodus, In the Future does not conclude on an optimistic note but on the contrary finishes with images of the past blinking out of existence and the final phrase 'like a biblical plague'. This apocalyptic tone and vision of destruction weakens the hope that time might provide some sort of redemption, or posthumous vindication.

That Sansour's films, including In the Future, do not offer the viewer univocally appealing visions of a bright Palestinian future should not be taken as some kind of creative deficiency on their part, or as an assumption of political quietism. By the same token, the idea that any imaginings of a Palestinian future are apolitical 'escapism' also falls wide of the mark. As Jameson argues,

the most characteristic SF does not seriously attempt to imagine the 'real' future of our social system. Rather, its multiple mock futures serve the quite different function of transforming our own present into the determinate past of something yet to come. It is this present moment... that upon our return from the imaginary constructs of SF is offered to us in the form of some future world's remote past, as if posthumous and as though collectively remembered. (p. 288)

Sansour's oeuvre, particularly In the Future, partakes of precisely this movement from the future to our time. On returning from viewing her films and installations, I would argue, we apprehend the historicity of Sansour's present, our present, in new ways, having contemplated the possibility of a posthumous and collectively remembered Palestinian future past. The collective aspect that Jameson picks out is highly significant in that all of Sansour's films to date show the enmeshing of the individual and the collective. From the solitary astronaut on the moon in A Space Exodus making 'one small step for a Palestinian', to the pregnant woman alone in her apartment gazing at Jerusalem in Nation Estate to the resistance leader blinking at the camera at the end of In the Future, the figures standing on the cusp of the future are all conscious of belonging to a wider group whose potential fate enfolds their own. Their individuality is asserted but this individualization is balanced by their awareness of what they might share with others, both those who are gone and those who are yet to be. We can see in this artist's work a development of science fiction tropes in an increasingly self-reflexive mode, starting from films that use family members and moving toward the creation a specific character who questions her contribution to the collective future of her people. 
The narrow question of 'failure' or 'viability' sometimes thrown at sf visions of the future, utopian or dystopian or a mixture of both, may therefore be something of a distraction from the more fundamental shifts in perspective enabled by the genre. Sansour's films are not in any sense a 'roadmap' that we might be tempted to follow. Instead, while her work voyages into both the past and the future, it is our present position in time and space that we always reassess, fulfilling perhaps the genre's most vital role:

We must therefore now return to the relationship of SF and future history and reverse the stereotypical description of this genre: what is indeed authentic about it, as a mode of narrative and a form of knowledge, is not at all its capacity to keep the future alive, even in imagination. On the contrary, its deepest vocation is over and over again to demonstrate and to dramatize our incapacity to imagine the future, ... to succeed by failure, and to serve as unwitting and even unwilling vehicles for a meditation, which, setting forth for the unknown, finds itself irrevocably mired in the all-too-familiar, and thereby becomes unexpectedly transformed into a contemplation of our own absolute limits. (Jameson pp. 288-289)

For Jameson, it is the cognitive transition from imagined futures to our present moment that is the key aspect of science fiction, and we might add that the Palestinian present is both 'mired in the all-too-familiar' and defined by limits to an uncommonly high degree. As this article has endeavoured to show, Sansour is a fascinating example of an artist who uses science fiction to evoke the deep psychological and social need to hold onto to some aspects of the past and of memory while orienting her own artistic practice around anxiety about the disappearance of a Palestinian future. Mahmoud Darwish, in an interview near the end of his life, stated that

Our permanent literary problem, we Palestinians, is that we are condemned to be the children of the immediate moment; for our present has not been determined, neither to begin nor end. (Darwish et al., p. 433)

It is out of this temporal 'problem' that Sansour's art has grown, and as her work has developed over the years, we as viewers have become increasingly aware of the limits of our own shared world, and reacquainted ourselves with the 'all-too-familiar' aspects of life for Palestinians, having seen our current order of things as the distant object of archaeologies of the future.

\footnotetext{
${ }^{1}$ https://www.theguardian.com/artanddesign/2011/dec/22/lacoste-palestinian-elyseeart-prize

2 'The late Shimon Peres, who died three months ago, once said the tragedy of the Israeli-Palestinian dispute was that while there was light at the end of the tunnel, the problem was that there was no tunnel. In other words, all people of goodwill knew what any long-term solution should look like - two co-existing and neighbouring states, one Jewish and one Palestinian. But the way forward was blocked by political obstacles to reaching such a solution.' 'Think Again, Israel' Leader The Times 7 Dec 2016
} 
${ }^{3}$ https://www.theguardian.com/world/2019/sep/20/pepsi-vs-coke-gaza-finds-littledifference-between-israels-deadlocked-parties

${ }^{4}$ see http://www.arabicmusictranslation.com/2009/09/rosanna-al-rozana.html

\section{Bibliography}

Abdeljawad, Abdellatif R. (2016) 'Unbreakable - interview with Larissa Sansour' REORIENT. Retrieved from http://www.reorientmag.com/2016/02/larissa$\underline{\text { sansour/ }}$

Abu el-Haj, Nadia (2001) Facts on the Ground: Archaeological Practice and Territorial Self-fashioning in Israeli Society Chicago: University of Chicago Press

Ashcroft, Bill (2017) Utopianism in Postcolonial Literature London: Routledge

Bar-Yosef, Eitan (2005) The Holy Land in English Culture 1799-1917: Palestine and the Question of Orientalism Oxford: Clarendon

Bouarrouj, Khelil (2015) "“Bethlehem Bandolero," Interview with Artist Larissa Sansour' Institute for Palestine Studies. Retrieved from https://palestinesquare.com/2015/04/20/larissa-sansour-on-sci-fi-nostalgiaand-the-staging-of-myth/

Campbell, Ian (2018) Arabic Science Fiction London: Palgrave Macmillan

Clute, John, and David Langford (2019) 'Ruins and Futurity.' The Encyclopedia of Science Fiction. Eds. John Clute, David Langford, Peter Nicholls and Graham Sleight. Gollancz. Retrieved from http://www.sfencyclopedia.com/entry/ruins_and_futurity.

Darwish, Mahmoud (2001) 'Our catastrophe was the creation of Israel' The Guardian 14 May 2001. Retrieved from https://www.theguardian.com/world/2001/may/14/comment.israelandthepalest $\underline{\text { inians }}$

Darwish, Mahmoud, et al. (2019) 'Our Present Does Not Decide Either to Begin or to End.' The Massachusetts Review, vol. 60 no. 3 (pp. 425-438)

Davis, Rochelle and Dan Walsh (2015) "Visit Palestine": a Brief Study of Palestine Posters' Jerusalem Quarterly 61 (pp. 42-54)

Delgado-García, Cristina (2015) 'Invisible Spaces for the "Impossible" State' ImageTexT: Interdisciplinary Comics Studies 8:1 Retrieved from http://www.english.ufl.edu/imagetext/archives/v8_1/delgado/

Dillon, Brian (2014) Ruin Lust: Artists' Fascination With Ruins, from Turner to the Present Day London: Tate

Duffy, Cian (2013) The Landscapes of the Sublime, 1700-1830 Basingstoke: Palgrave

Eshun, Kodwo (2003) 'Further Considerations on Afrofuturism' CR: The New Centennial Review, vol. 3 no. 2 (pp. 287-302) 
Jameson, Fredric (2005) Archaeologies of the Future: the Desire called Utopia and Other Science Fictions London: Verso

Orwell, George (1987) Nineteen Eighty-Four Complete Works Vol. 9 London: Secker and Warburg (novel first published 1949)

Sacco, Joe (2001) Palestine London: Jonathan Cape

Said, Edward (1979) The Question of Palestine New York: Vintage

Sansour, Larissa (dir.) (2009) A Space Exodus

---- (dir.) (2012) Nation Estate

---- (dir.) (2016) In the Future They Ate from the Finest Porcelain

Shelley, Mary (1980) Frankenstein, or The Modern Prometheus Oxford: Oxford World Classics

Siegman, Henry (2018) 'The Two-State Solution: An Autopsy' London Review of Books vol. 40 no.10 (pp. 17-18)

Stolfi, Carmen (2016) 'Time, nationhood, resistance: Larissa Sansour's latest film "In The Future They Ate From The Finest Porcelain" - interview' Art Radar. Retrieved from https://artradarjournal.com/2016/02/01/palestinian-artistlarissa-sansours-interview/

Suleiman, Elia (dir.) (2002) Divine Intervention

Weizman, Eyal (2007) Hollow Land: Israel's Architecture of Occupation London: Verso

--- (2017) 'The Vertical Apartheid' Open Democracy. Retrieved from https://www.opendemocracy.net/en/north-africa-west-asia/vertical-apartheid/

Volney, Constantin-Francois (1792) The Ruins: or a Survey of the Revolutions of Empires London: printed for J. Johnson 